\title{
Impact of Smoking Cigarette on the mRNA Expression of Cytokines in Mucosa of Inflammatory Bowel Disease
}

\author{
Z. VRABLICOVA ${ }^{1}$, K. SOLTYS ${ }^{2}$, A. KRAJCOVICOVA ${ }^{1}$, K. STUCHLIKOVA ${ }^{2}$, \\ I. STURDIK ${ }^{1}$, T. KOLLER ${ }^{1}$, M. HUORKA ${ }^{1}$, J. PAYER ${ }^{1}$, Z. KILLINGER ${ }^{1}$, P. JACKULIAK ${ }^{1}$, \\ M. TKACIK ${ }^{1,3}$, S. STUCHLIK ${ }^{2}$, J. SEKAC ${ }^{4}$, T. HLAVATY ${ }^{1}$ \\ ${ }^{1} 5$ th Department of Internal Medicine, Sub-department of Gastroenterology and Hepatology, \\ Faculty of Medicine, Comenius University Bratislava, University Hospital Bratislava, Slovak \\ Republic, ${ }^{2}$ Department of Molecular Biology, Faculty of Natural Sciences, Comenius University \\ Bratislava, Slovak Republic, ${ }^{3}$ Department of Internal Medicine, Hospital with Polyclinic, \\ Brezno, Slovak Republic, ${ }^{4}$ 2nd Surgical Department, Faculty of Medicine, Comenius University \\ Bratislava, University Hospital Bratislava, Slovak Republic
}

Received May 27, 2019

Accepted September 23, 2019

\section{Summary}

It is well known that smoking is the risk factor in the development and clinical course of Crohn's disease (CD), but on the other hand, smoking is a protective factor against ulcerative colitis (UC). The pathways that are influenced by smoking in $C D$ and UC are poorly understood. The aim of our study was to analyse the influence of smoking on the mRNA expression of cytokines in mucosa in patients with $C D$ and UC. We performed a cross-sectional study. The cohort consisted of 86 IBD patients (48 CD patients and 38 UC patients) and took place at the IBD Centre at the University Hospital Bratislava-Ružinov. We took the demographic and clinical data of each patient, including information about their smoking habits. We performed a colonoscopy on each patient and took biopsies from both inflamed and non-inflamed sigma (CD, UC) and terminal ileum (CD). mRNA was extracted from mucosal biopsy samples for each cytokine and was normalized to a housekeeping gene (GAPDH). Finally, we compared the mRNA expression of target cytokines in the mucosa of smokers and non-smokers in IBD patients. Smokers with Crohn's disease have a significantly higher mRNA expression of pro-inflammatory cytokine TNF- $\alpha$ $(p=0.003)$ in inflamed mucosa in sigma compared with non-smokers. In smokers with ulcerative colitis, we observed significantly higher mRNA expression of anti-inflammatory cytokine IL $10(p=0.022)$ in non-inflamed mucosa of sigma. Similarly, smokers with UC have a significantly decreased mRNA expression of cytokine TLR $2(p=0.024)$ and CCR1 $(p=0.049)$ in non-inflamed mucosa of sigma. Based on our results, smoking has a positive influence on cessation and the clinical course of UC due to the stimulation of anti-inflammatory cytokine IL 10 in mucosa. On the other hand, smokers with $C D$ have a higher expression of pro-inflammatory cytokine TNF- $\alpha$, which could be associated with a worsening of the disease and response to therapy.

\section{Key words}

Inflammatory bowel disease - Mucosa • mRNA cytokine • Smoking

\section{Corresponding author}

T. Hlavaty, $5^{\text {th }}$ Department of Internal Medicine, Faculty of Medicine, Comenius University and University Hospital, Ruzinovska 6, 82606 Bratislava, Slovak Republic. E-mail: tibor.hlavaty2@gmail.com

\section{Introduction}

Inflammatory bowel diseases (IBDs) are chronic recurring inflammatory gastrointestinal diseases that comprise Crohn's disease (CD) and ulcerative colitis (UC). The etiology of IBD arises from a complex interplay between host genotypes, the immune system and environmental factors (Berkowitz et al. 2018).

Smoking is a known risk factor for CD that is 
associated with the worsening of the illness and quality of life, a higher rate of hospitalization (Golovics et al. 2015), a higher recurrence after surgery (Yamamoto and Keighley 2000), and a poor response to medical therapy (Parkes et al. 2014). The detrimental effects of smoking on $\mathrm{CD}$ are ascribed to damaged mucosal barriers due to an increase in intestinal permeability and an alteration of tight junctions (Allais et al. 2016, Zuo et al. 2014) as well as affected gut microbiota. The dysbiosis of gut microbiota is characterized by an increase in Firmicutes and Actinetobacteria and a decrease in Bacteroides and Proteobacteria (Biedermann et al. 2014). Smoking also alters microcirculation and significantly reduces blood flow to the gastrointestinal mucosa (Zuo et al. 2014). Nevertheless, cigarette smoking causes an influx of neutrophils and CD4+ INF $\gamma^{+} \mathrm{T}$ cells into intestinal mucosa (Allais et al. 2017, Verschuere et al. 2011).

These results cause an injury in the epithelium that leads to the exposure of lumen antigens which can be recognized by immune cells whose recruitment is increased, inducing the development of CD (Ueno et al. 2014). Moreover, cigarette smoking upregulates the mRNA expression of cytokines of Th-1 response such as CCL9, CCL20 and IL-1, three important chemokines in the pathogenesis of CD (Lee et al. 2017, Oberg et al. 2011, Verschuere et al. 2011).

Conversely, smoking appears protective against ulcerative colitis and UC smokers are less likely to need hospitalization, potent drugs or require a colectomy (Mahid et al. 2006). A beneficial effect of nicotine in UC is explained by the activation of the nicotinic receptors $\alpha 7$ $(\alpha 7-\mathrm{nAChR})$ in immune cells such as macrophages and dendritic cells (de Souza and Fiocchi 2016). The stimulation of these receptors $\alpha 7$ ( $\alpha 7$-nAChR) by nicotine leads to the decreased production of pro-inflammatory cytokines TNF- $\alpha$ and IL-2 and suppresses the function of $\mathrm{CD}^{+} \mathrm{CD} 25^{+}$regulatory $\mathrm{T}$ cells (Lakhan and Kirchgessner 2011, Gomes et al. 2018). Additionally, the $\alpha 7-n A C h R$ receptor is also expressed by endothelial cells, where its activation decreases the production of chemokines and the expression of adhesion molecules in the endothelium. This mechanism can help to modulate leukocyte migration and inflammation (Saeed et al. 2005).

Consistently, a French study performed by Seksik et al. (2009) has shown that CD non-smokers spent less time with the active disease compared to $\mathrm{CD}$ smokers. In a cohort of UC patients, a reduction in oral corticosteroid use and colectomy rates in UC smokers was found. Two further studies published similar results, showing that continued smoking is a risk factor for worsening the disease based on the Montreal Classification (disease progression from B1 to B2/B3) (Lakatos et al. 2013, Lawrance et al. 2013).

Tabaco smoke contains more than 4500 chemicals, among these nicotine, carbon monoxide (CO), and nitrogen oxide are known to have immunomodulatory capacities as well as to interact with intestinal immunity and gut function. The first tissues that interact directly with cigarette smoke are in the respiratory and gastrointestinal tracts, where it can affect local immune response (Talhout et al. 2011). The pathways by which cigarette smoking exerts the opposite effect in CD and UC have not been fully clarified yet.

\section{Aim of the study}

The aim of this study was to identify whether and how smoking affects the mucosal immune system, especially the mRNA expression of cytokines in the mucosa of IBD patients.

\section{Methods}

\section{Study design}

Consecutive patients with inflammatory bowel disease who underwent a colonoscopy between February and October 2013 were included in this cross-sectional study. All of these IBD patients were followed-up with at the $5^{\text {th }}$ Department of Internal Medicine, Sub-department of Gastroenterology and Hepatology of the University Hospital in Bratislava Ruzinov and the Faculty of Medicine of Comenius University in Bratislava. Clinical information including smoking habits was obtained from each patient at the time of the colonoscopy. During the colonoscopy, biopsies were taken from inflamed and non-inflamed mucosa. Mucosal samples were collected for an extraction of mRNA for each cytokine. Finally, we compared the mRNA expression of cytokines in the intestinal mucosa between smoking and non-smoking IBD patients.

\section{Cohort}

Mucosal biopsy samples were collected from 86 patients with IBD ( 48 with CD, 38 with UC) during the colonoscopy. The diagnosis of $\mathrm{CD}$ as well as $\mathrm{UC}$ was established by standard clinical, endoscopic and histological criteria and classified according the Montreal Classifications. (22) Among CD patients, 38 were 
non-smokers and 10 were smokers. The UC cohort consisted of 30 non-smokers and 8 UC smokers. Additional data of IBD patients is included in Table 1.

\section{Tobacco use}

The smoking status of all patients was categorized into "never being smokers" and "former smokers" as non-smokers, which comprised answers in a questionnaire and "current smokers" as smokers. From "current smokers," the average number of cigarettes per day was recorded.
Colonoscopy and biopsies

In $\mathrm{CD}$ patients, during the colonoscopy we took biopsy specimens from the terminal ileum and sigma from the inflamed mucosa and if applicable also from the non-inflamed mucosa. Biopsy specimens from the sigma were collected in the same manner from UC patients. Inflamed mucosa was defined as the presence of marked hyperaemia, friability, erosions or ulcers. The obtained mucosal biopsies were immediately immersed in an RNA stabilizing solution (RNA later, Qiagen) until processed and sent for mRNA cytokines analysis the same day.

Table 1. Clinical characteristics of IBD smokers and non-smokers according Montreal classification

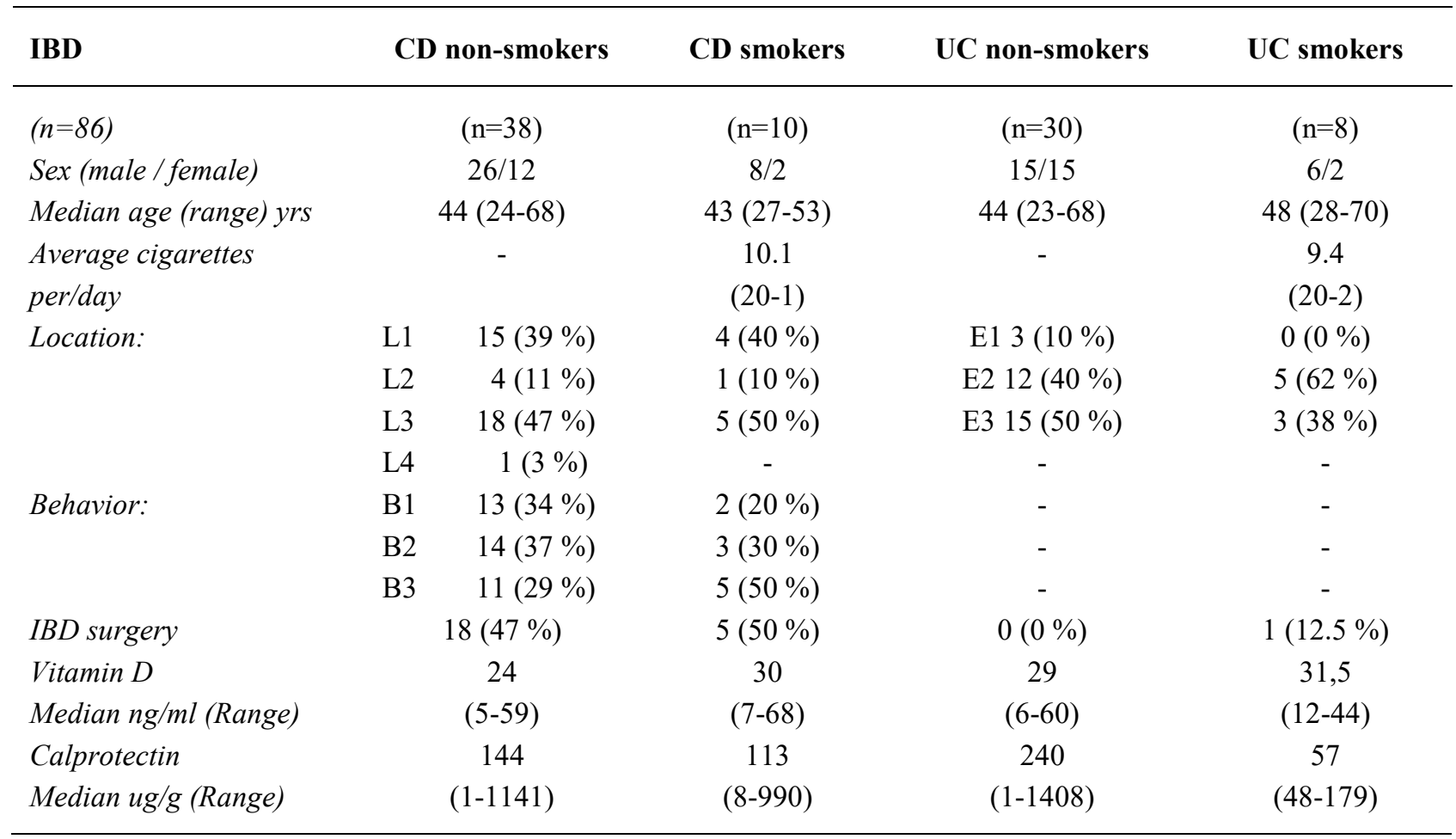

Table 2. Colonoscopy biopsies samples of IBD patients

\begin{tabular}{lcccc}
\hline $\begin{array}{l}\text { Analyzed tissue samples } \\
(\mathbf{n = 1 7 9 )}\end{array}$ & \multicolumn{2}{c}{ Sigma $(\mathbf{n = 1 1 6 )}$} & Terminal ileum (n=63) \\
\hline & $\begin{array}{c}\text { Non-inflamed } \\
(\mathrm{n}=78)\end{array}$ & $\begin{array}{c}\text { Inflamed } \\
(\mathrm{n}=38)\end{array}$ & $\begin{array}{c}\text { Non-inflamed } \\
(\mathrm{n}=37)\end{array}$ & $\begin{array}{c}\text { Inflamed } \\
(\mathrm{n}=26)\end{array}$ \\
Ulcerative colitis & 44 & 24 & - & - \\
Crohn's disease & 34 & 14 & 37 & 26 \\
\hline
\end{tabular}

Real time PCR (RT-qPCR)

Tissue RNA was isolated by RNeasy Mini Kit (QIAGEN) for each cytokine (TNF- $\alpha$, FOXP3, IL-6, IL8,
IL-10, IL-12, IL-17, IL-23, TLR2, TLR4, TLR5 CCR1, CCR2, CCR5, CCR9, CCL5, CD207, CD 206) according to the manufacturer's instructions. RNA samples of the 
Table 3. Comparison of the mRNA expression of cytokines between CD smokers and CD non-smokers in sigma

\begin{tabular}{|c|c|c|c|c|c|}
\hline \multicolumn{6}{|c|}{ Non inflamed sigma } \\
\hline $\begin{array}{l}\text { mRNA } \\
\text { cytokine }\end{array}$ & $\begin{array}{c}\text { Mean smokers } \\
\Delta \mathrm{C} 1 \\
\end{array}$ & Std. deviation & $\begin{array}{c}\text { Mean non-smokers } \\
\Delta \mathrm{C} 2 \\
\end{array}$ & Std. deviation & $\mathbf{P}$ \\
\hline IL 6 & -10.958 & 3.844 & -11.841 & 2.658 & 0.301 \\
\hline$I L 8$ & -8.949 & 3.123 & -9.533 & 2.770 & 0.750 \\
\hline IL 10 & -11.457 & 3.967 & -11.982 & 2.423 & 0.182 \\
\hline IL12 & -11.431 & 3.852 & -12.212 & 2.513 & 0.252 \\
\hline IL 17 & -11.537 & 3.846 & -12.493 & 2.560 & 0.279 \\
\hline IL 23 & -11.025 & 3.841 & -11.231 & 2.337 & 0.169 \\
\hline$T L R 2$ & -10.321 & 3.663 & -11.133 & 2.252 & 0.121 \\
\hline$T L R 4$ & -11.440 & 2.914 & -12.384 & 1.867 & 0.846 \\
\hline TLR 5 & -10.166 & 3.465 & -10.812 & 1.988 & 0.209 \\
\hline$C D 206$ & -8.401 & 2.690 & -8.656 & 1.509 & 0.195 \\
\hline$C D 207$ & -9.228 & 2.340 & -10.097 & 1.832 & 0.537 \\
\hline CCL 5 & -6.615 & 2.323 & -7.002 & 1.179 & 0.105 \\
\hline CCR 1 & -8.546 & 2.061 & -9.448 & 1.762 & 0.703 \\
\hline$C C R 2$ & -10.524 & 5.110 & -10.660 & 2.442 & 0.051 \\
\hline CCR 5 & -8.053 & 2.676 & -8.707 & 1.610 & 0.189 \\
\hline$C C R 9$ & -7.980 & 1.593 & -9.096 & 1.768 & 0.244 \\
\hline FOXP3 & -8.487 & 2.183 & -9.318 & 1.681 & 0.849 \\
\hline$T N F \alpha$ & -8.643 & 1.195 & -8.938 & 1.480 & 0.482 \\
\hline \multicolumn{6}{|c|}{ Inflamed sigma } \\
\hline $\begin{array}{l}\text { mRNA } \\
\text { cytokine }\end{array}$ & $\begin{array}{c}\text { Mean smokers } \\
\Delta \mathrm{C} 1\end{array}$ & Std. deviation & $\begin{array}{c}\text { Mean non-smokers } \\
\Delta \mathrm{C} 2\end{array}$ & Std. deviation & $\mathbf{P}$ \\
\hline IL 6 & -12.590 & 0.192 & -11.434 & 2.487 & 0.093 \\
\hline IL 8 & -8.415 & 1.993 & -7.467 & 3.231 & 0.440 \\
\hline IL 10 & -12.503 & 0.880 & -11.852 & 1.413 & 0.325 \\
\hline IL 12 & -12.386 & 0.401 & -12.348 & 0.964 & 0.170 \\
\hline IL 17 & -11.590 & 0.192 & -12.358 & 0.819 & 0.233 \\
\hline IL 23 & -11.770 & 0.741 & -10.238 & 1.645 & 0.164 \\
\hline$T L R 2$ & -10.642 & 2.313 & -9.884 & 2.157 & 0.922 \\
\hline$T L R 4$ & -12.372 & 1.676 & -12.886 & 1.209 & 0.747 \\
\hline TLR 5 & -10.185 & 1.486 & -10.725 & 0.940 & 0.552 \\
\hline$C D 206$ & -9.284 & 1.141 & -8.570 & 1.200 & 0.976 \\
\hline$C D 207$ & -11.071 & 0.652 & -10.620 & 0.773 & 0.845 \\
\hline$C C L 5$ & -7.397 & 0.528 & -7.008 & 0.651 & 0.529 \\
\hline$C C R 1$ & -9.689 & 1.191 & -7.940 & 2.029 & 0.486 \\
\hline CCR 2 & -10.803 & 0.773 & -10.569 & 1.157 & 0.426 \\
\hline CCR 5 & -9.130 & 1.286 & -7.953 & 1.195 & 0.849 \\
\hline CCR 9 & -9.054 & 2.016 & -10.022 & 1.327 & 0.563 \\
\hline FOXP3 & -9521 & 1.773 & -8.300 & 1.500 & 0.681 \\
\hline$T N F \alpha$ & -7.860 & 1.392 & -9.927 & 0.526 & 0.003 \\
\hline
\end{tabular}

$\triangle \mathrm{C} 1$ represents the difference in the number of PCR cycles needed to express the mRNA of the house keeping gene GAPDH and the number of PCR cycles needed to express the mRNA of the target cytokine of smokers with IBD, $\Delta C=(\Delta C$ house-keeping gene $\triangle C$ cytokines), $\triangle C 2$ represents the difference in the number of PCR cycles needed to express the mRNA of the house keeping gene GAPDH and the number of PCR cycles needed to express the mRNA of the target cytokine of non- smokers with IBD, $\Delta C=(\Delta C$ housekeeping gene - $\Delta \mathrm{C}$ cytokines), $\mathrm{P}$ : two-tailed $\mathrm{p}$-value evaluating the null hypothesis against an alternative hypothesis 
cytokines were converted to cDNA using Thermo Scientific Maxima H Minus First Strand cDNA Synthesis K. DNA was isolated with a DN-easy Blood \& Tissue Kit (QIAGEN). The quality and quantity of RNA was screened by an Agilent RNA 6000 Nano Kit. The gene expression of cytokines was analyzed by a custom array gene expression kit (QIAGEN) including house-keeping gene (Glyceraldehyde 3-phosphate dehydrogenase, GAPDH). Data were analyzed by RT2 Profiler PCR Array Data Analysis v3.5 software (QIAGEN). Next, we analyzed the difference between the expression of mRNA of the target cytokine and the expression of mRNA of the housekeeping gene, GAPDH. The difference was expressed as $\Delta \mathrm{C}$, which represents the difference in the number of PCR cycles needed to express the mRNA of the house keeping gene GAPDH ( $\left.\Delta \mathrm{C}_{\text {house-keeping gene }}\right)$ and the number of PCR cycles needed to express the mRNA of the target cytokine $\left(\Delta \mathrm{C}_{\text {cytokine }}\right) . \Delta \mathrm{C}=\left(\Delta \mathrm{C}_{\text {house-keeping gene }}-\Delta \mathrm{C}_{\text {cytokine }}\right)$.

\section{Statistical analysis}

Statistical analyses were performed using SPSS 19.0 (IBM SPSS Inc., Chicago, Illinois, United States). Nominal and ordinal variables such as clinical characteristics were analyzed using the Chi square test with Yate's correction. If any cell of the contingency table contained a value of less than 5, Fisher's exact test was used instead. The Kolmogorov-Smirnov test was used to analyze the normality of the distribution of measured parameters (age, duration of the disease, VD serum concentration). We compared the mRNA expression of cytokines ( $\Delta \mathrm{C}$, see above) between smokers and non-smokers in inflamed and non-inflamed mucosa using a paired sample - T test in patients with ulcerative colitis (sigma) as well as in patients with Crohn's disease (sigma/terminal ileum). Statistical significance was considered at a level of $\mathrm{P}<0.05$.

\section{Ethical considerations}

The study was approved by the local ethical committee. All the subjects gave their written informed consent to participate in the study.

\section{Results}

\section{Study population}

Study cohort consists of 86 IBD patients, 48 patients with Crohn's disease and 38 patients with ulcerative colitis. One patient with ulcerative colitis has left hemicolectomy prior to entering the study, we took biopsy samples from non-inflamed sigma.
Analyses of the expression of mRNA of cytokines between smokers and non-smokers in CD patients

Firstly, we found out a significantly higher the mRNA expression of cytokines TNF- $\alpha\left(\Delta \mathrm{C}_{1}=-7.860 \pm 1.392\right.$ smokers vs. $\Delta \mathrm{C}_{2}=-9.927 \pm 0.526$ non-smokers, $\left.\mathrm{p}=0.003\right)$ in inflamed mucosa of sigma of CD smokers (Table 4). Another our analyses did not show any differences between smokers and non-smokers in non-inflamed terminal ileum as well as inflamed terminal ileum (Table 3).

Analyses of the expression of mRNA of cytokines between smokers and non-smokers in UC patients

Next, we analyzed the mRNA expression of cytokines in non-inflamed mucosa of sigma in UC smokers and non-smokers patients (Table 3). We observed a significantly higher mRNA expression of cytokines IL $10\left(\Delta \mathrm{C}_{1}=-10.862 \pm 5.174\right.$ smokers vs. $\Delta \mathrm{C}_{2}=$ $-12.576 \pm 1.688$ non-smokers, $p=0.022$ ) in UC smokers. There was also significant lower expression of mRNA of cytokines TLR $2\left(\Delta \mathrm{C}_{1}=-12.240 \pm 0.873\right.$ smokers vs. $\Delta \mathrm{C}_{2}=-11.107 \pm 1.621$ non-smokers, $\left.\mathrm{p}=0.024\right)$ and CCR1 $\left(\Delta \mathrm{C}_{1}=-10.197 \pm 0.572\right.$ smokers vs. $\Delta \mathrm{C}_{2}=-9.662 \pm 1.071$ non-smokers, $\mathrm{p}=0.049$ ) in smokers (Table 5).

In the same group of patients, biopsy samples could not be obtained from inflamed mucosa of sigma, as the patients had only a non-inflamed mucosa of sigma.

\section{Discussion}

Presented results showed a significant increase in the mRNA expression of TNF- $\alpha$ in the inflamed mucosa of sigma in the subgroup of CD smokers compared to CD non-smokers. This explains that smoking might cause the increased recruitment of CD4+ and $\mathrm{CD} 8+$ $\mathrm{T}$ cells as well as CD11b+ dendritic cells in the mucosa of the colon (Allais et al. 2017, Arnson et al. 2010). These immune cells produce a large number of Th1/Th17-associated pro-inflammatory cytokines such as IFN- $\gamma$, IL-17A, and TNF- $\alpha$ (Lackeyram et al. 2017). The highest mRNA expression of TNF- $\alpha$ is in the first stage of the establishment of the disease (Zorzi et al. 2013, Baumgart and Sandborn 2012). The molecular mechanism at least could be partially responsible for the immunomodulation capabilities of smoking involves the activation of NF- $\kappa \mathrm{B}$ nuclear translocation. According to recent studies, $\mathrm{NF}-\kappa \mathrm{B}$ is a key transcription factor regulating the mRNA expression of various pro-inflammatory cytokines and its activation leads to a higher mRNA expression of pro-inflammatory cytokines, especially TNF- $\alpha$, in smokers (Hasnis et al. 2007). 
Table 4. Comparison of the mRNA expression of cytokines between CD smokers and CD non-smokers in terminal ileum

\begin{tabular}{|c|c|c|c|c|c|}
\hline \multicolumn{6}{|c|}{ Non inflamed terminal ileum } \\
\hline $\begin{array}{l}\text { mRNA } \\
\text { cytokine }\end{array}$ & $\begin{array}{c}\text { Mean smokers } \\
\qquad \Delta \mathrm{C}^{1}\end{array}$ & Std. deviation & $\begin{array}{c}\text { Mean non-smokers } \\
\qquad \Delta \mathbf{C}^{2}\end{array}$ & Std. deviation & $\mathbf{P}$ \\
\hline IL 6 & -12.588 & 0.917 & -11.860 & 2.675 & 0.195 \\
\hline IL 8 & -9.172 & 2.958 & -9.010 & 2.245 & 0.469 \\
\hline IL10 & -12.013 & 3.318 & -12.255 & 2.087 & 0.290 \\
\hline IL12 & -12.172 & 3.358 & -12.142 & 2.160 & 0.340 \\
\hline IL 17 & $-12,157$ & 3.992 & -12.783 & 2.322 & 0.174 \\
\hline IL 23 & -11.537 & 3.846 & -12.493 & 2.176 & 0.471 \\
\hline$T L R 2$ & -9.731 & 1.981 & -9.550 & 1.738 & 0.486 \\
\hline$T L R 4$ & -11.919 & 2.048 & -12.225 & 1.424 & 0.236 \\
\hline TLR 5 & -10.439 & 2.647 & -10.818 & 1.621 & 0.130 \\
\hline$C D 206$ & -8.746 & 1.800 & -8.356 & 1.054 & 0.491 \\
\hline$C D 207$ & -9.353 & 1.662 & -9.382 & 1.681 & 0.923 \\
\hline CCL 5 & -5.902 & 1.369 & -5.903 & 1.280 & 0.656 \\
\hline$C C R 1$ & -8.857 & 1.141 & -8.670 & 1.067 & 0.825 \\
\hline$C C R 2$ & -10.775 & 2.952 & -10.569 & 2.074 & 0.615 \\
\hline CCR 5 & -7.633 & 1.974 & -7.727 & 1.665 & 0.147 \\
\hline CCR 9 & $-9,972$ & 2.249 & -10.688 & 2.047 & 0.567 \\
\hline FOXP3 & -8.987 & 2.182 & -9.107 & 1.717 & 0.553 \\
\hline$T N F \alpha$ & -8.104 & 1.259 & -8.257 & 1.319 & 0.778 \\
\hline \multicolumn{6}{|c|}{ Inflamed terminal ileum } \\
\hline $\begin{array}{l}\text { mRNA } \\
\text { cytokine }\end{array}$ & $\begin{array}{c}\text { Mean smokers } \\
\Delta \mathrm{C}^{1}\end{array}$ & Std. deviation & $\begin{array}{c}\text { Mean non-smokers } \\
\Delta \mathbf{C}^{2}\end{array}$ & Std. deviation & $\mathbf{P}$ \\
\hline$I L 6$ & -8.951 & 3.274 & -9.587 & 3.556 & 0.822 \\
\hline$I L 8$ & -4.264 & 4.182 & -5.462 & 3.005 & 0.114 \\
\hline IL10 & -10.754 & 1.629 & -10.915 & 2.760 & 0.364 \\
\hline IL 12 & -12.604 & 0.877 & -12.127 & 2.932 & 0.193 \\
\hline IL 17 & -12.843 & 0.725 & -12.943 & 2.746 & 0.245 \\
\hline IL 23 & -9.992 & 1.646 & -9.686 & 2.649 & 0.343 \\
\hline$T L R 2$ & -8.203 & 2552 & -8.421 & 2.462 & 0.121 \\
\hline$T L R 4$ & -11.957 & 1.404 & -12.471 & 2.225 & 0.482 \\
\hline$T L R 5$ & -10.559 & 1.379 & -10.383 & 2.116 & 0.554 \\
\hline CD 206 & -7.421 & 1.148 & -7.960 & 1.690 & 0.609 \\
\hline CD 207 & -10.332 & 0.834 & -10.196 & 1.881 & 0.351 \\
\hline CCL 5 & -7.461 & 1.508 & -6.967 & 1.547 & 0.981 \\
\hline$C C R 1$ & -6.398 & 2.009 & -6.908 & 2.209 & 0.743 \\
\hline$C C R 2$ & -9.403 & 1.451 & -9.685 & 2.505 & 0.264 \\
\hline CCR 5 & -7.204 & 1.222 & -7.430 & 1.815 & 0.420 \\
\hline CCR 9 & -10.812 & 0.974 & -10.328 & 1.916 & 0.634 \\
\hline FOXP3 & -7.633 & 1.616 & -7.946 & 1.726 & 0.741 \\
\hline$T N F \alpha$ & -7.487 & 1.611 & -7.250 & 2.213 & 0.489 \\
\hline
\end{tabular}

$\triangle \mathrm{C} 1$ represents the difference in the number of PCR cycles needed to express the mRNA of the house keeping gene GAPDH and the number of PCR cycles needed to express the mRNA of the target cytokine of smokers with IBD, $\Delta C=(\Delta C$ house-keeping gene $\triangle C$ cytokines), $\triangle C 2$ represents the difference in the number of PCR cycles needed to express the mRNA of the house keeping gene GAPDH and the number of PCR cycles needed to express the mRNA of the target cytokine of non- smokers with IBD, $\triangle \mathrm{C}=$ ( $\Delta$ C house-keeping gene $-\Delta C$ cytokines), $\mathrm{P}$ : two-tailed $\mathrm{p}$-value evaluating the null hypothesis against an alternative hypothesis 
Table 5. Comparison of the mRNA expression of cytokines between UC smokers and non-smokers in non-inflamed sigma

\begin{tabular}{|c|c|c|c|c|c|}
\hline \multirow[b]{2}{*}{$\begin{array}{l}\text { mRNA } \\
\text { cytokine }\end{array}$} & \multicolumn{3}{|c|}{ Non inflamed sigma } & \multirow[b]{2}{*}{ Std. deviation } & \multirow[b]{2}{*}{$\mathbf{p}$} \\
\hline & $\begin{array}{l}\text { Mean } \Delta C 1 \\
\text { in smokers }\end{array}$ & Std. deviation & $\begin{array}{c}\text { Mean } \Delta C 2 \\
\text { in non-smokers }\end{array}$ & & \\
\hline IL 6 & -13.132 & 1.736 & -12.968 & 2.108 & 0.609 \\
\hline$I L 8$ & -11.208 & 1.015 & -10.922 & 2.370 & 0.232 \\
\hline IL10 & -10.862 & 5.714 & -12.576 & 1.688 & 0.022 \\
\hline IL12 & -13.104 & 1.514 & -12.846 & 0.985 & 0.413 \\
\hline IL 17 & -14.100 & 2.033 & -13.474 & 2.043 & 0.940 \\
\hline IL 23 & -11.776 & 1.078 & -11.900 & 1.658 & 0.409 \\
\hline$T L R 2$ & -12.240 & 0.873 & -11.107 & 1.621 & 0.024 \\
\hline$T L R 4$ & -11.730 & 1.022 & -11.910 & 1.218 & 0.977 \\
\hline TLR 5 & -11.245 & 1.318 & -10.733 & 1.031 & 0.683 \\
\hline$C D 206$ & -9.571 & 0.602 & -9.630 & 0.824 & 0.220 \\
\hline CD 207 & -11.640 & 1.293 & -10.799 & 0.994 & 0.437 \\
\hline$C C L 5$ & -7.773 & 0.725 & -7.552 & 1.084 & 0.262 \\
\hline CCR 1 & -10.197 & 0.572 & -9.662 & 1.071 & 0.049 \\
\hline$C C R 2$ & -11.680 & 1.506 & -10.968 & 1.953 & 0.446 \\
\hline CCR 5 & -9.384 & 1.003 & -9.503 & 0.860 & 0.868 \\
\hline$C C R 9$ & -8.856 & 1.290 & -8.804 & 1.457 & 0.827 \\
\hline FOXP3 & -10.093 & 0.694 & -10.313 & 0.875 & 0.589 \\
\hline$T N F \alpha$ & -10.013 & 1.220 & -9.634 & 0.933 & 0.181 \\
\hline
\end{tabular}

$\triangle \mathrm{C} 1$ represents the difference in the number of PCR cycles needed to express the mRNA of the house keeping gene GAPDH and the number of PCR cycles needed to express the mRNA of the target cytokine of smokers with IBD, $\Delta C=(\Delta C$ house-keeping gene $\triangle \mathrm{C}$ cytokines), $\triangle \mathrm{C} 2$ represents the difference in the number of PCR cycles needed to express the mRNA of the house keeping gene GAPDH and the number of PCR cycles needed to express the mRNA of the target cytokine of non- smokers with IBD, $\triangle \mathrm{C}=$ ( $\Delta \mathrm{C}$ house-keeping gene $-\Delta \mathrm{C}$ cytokines), $\mathrm{P}$ : two-tailed $\mathrm{p}$-value evaluating the null hypothesis against an alternative hypothesis

According to our results, smoking has a positive effect on the mucosa of sigma in patients with ulcerative colitis. UC smokers were characterized by a higher mRNA expression of anti-inflammatory cytokine IL-10.

In this context, several inherent pharmacological properties of cigarette smoke could explain this. Carbon monoxide (CO) as a component of the gas phase of cigarette smoke is associated with anti-inflammatory properties. $\mathrm{CO}$ reduces antigen presentation by APCs and prevents the maturation of dendritic cells (DCs) (Sheikh et al. 2011, Riquelme et al. 2016, Mackern-Oberti et al. 2015). CO-treated DCs retained the capacity to secrete anti-inflammatory cytokine IL-10 despite losing their ability to produce pro-inflammatory cytokine IL-12 (Riquelme et al. 2016).

However, the anti-inflammatory effect of cigarette smoke prevails in UC but not in ileal CD. This could be explained by the different expression of Aryl hydrocarbon (AhR) receptors. Stimulation by dioxide as a product of tobacco combustion induces an anti- inflammatory and protective response (Chinen et al. 2015). Monteleone et al. (2011) reported in their study that the expression of $\mathrm{AhR}$ is downregulated in inflamed CD tissue in contrast with inflamed UC tissue.

Our finding of an increased mRNA expression of IL-10 is in line with the results of Neisner and Volk (1995) who reported an elevated mRNA expression of IL-10 in biopsies from UC patients.

In our study, we found a significantly decreased mRNA expression of Toll-like receptor 2 (TLR2) in UC smokers in comparison with UC non-smokers in non-inflamed mucosa of sigma. Yuing Fan and colleagues in their study observed an overexpression of TLR2, TLR4, and TLR9 in the colonic mucosa of patients with UC (Fan and Liu 2015). The purpose of this receptor upregulation may be to increase the antigenic stimulation of inflammatory and immune pathways activated by ligand binding (Lee et al. 2006). Canto et al. (2006) identified an upregulated expression of TLR2 in peripheral blood monocytes which was associated with elevated circulating TNF- $\alpha$ concentrations in active UC and CD. Our study showed a significantly lower mRNA 
expression of TLR2, as well as a lower mRNA expression of TNF- $\alpha$, but in non-inflamed mucosa of sigma.

Finally, all of our UC smokers were also characterized by a significantly decreased mRNA expression of chemokine receptor CCR1 in non-inflamed mucosa in sigma compared to UC non-smokers. As for CCR1, the ligands for this receptor include CCL3, CCL5 (RANTES), CCL7, and CCL23 (Danese and Gasbarrini 2005). Several studies reported the increased expression of CCL3 and CCL5, mainly in intraepithelial lymphocytes and in the subepithelial lamina propria in colonic biopsies of UC and CD patients (Ajuebor et al. 2001, Mazzucchelli et al. 1996). This suggests that the role of CCL5/RANTES during chronic colitis appears to be attracting CCR1- and CCR5-bearing inflammatory cells into colonic tissue where the activation of these cells leads to tissue ulceration (Gunaltay et al. 2015, Andres et al. 2000). In our opinion, this reflected that ongoing tobacco (smoking) might suppress the mRNA expression of CCL5 and result in a decrease in the mRNA expression of its chemokine receptor CCR1. There is a lack of studies about the influence of smoking on the mRNA expression of chemokine receptors in patients with IBD.

To conclude, CD smokers had a significantly higher mRNA expression of the pro-inflammatory cytokine TNF- $\alpha$ in the inflamed mucosa of sigma compared to CD non-smokers. UC smokers had a significantly higher mRNA expression of antiinflammatory cytokine IL-10 in the non-inflamed mucosa of sigma compared to non-smokers. In the same group, we observed a significantly lower mRNA expression of TLR2 and CCR1 in the non-inflamed mucosa of sigma.

Although, nicotine showed positive effect on the expression mRNA cytokines in colonic mucosa of UC patients, it is not sufficient to treat UC. A number of clinical studies, that tested nicotine as a treatment, reported that nicotine lacks efficacy in treating disease relapses and remission (Pullan et al. 1994, Sanborn et al. 1997, Ingram et al. 2005). In addition, they also reported sides effects as a result of the high systemic nicotine concentrations required (Nikfar et al. 2010).

\section{Limitations}

The first limitation of this study is the moderate size of the cohort, which influenced the statistical power of the study. The second limitation is that our analyses did not cover the effects of therapy, which potentially may affect the mRNA expression of target cytokines. Thirdly, all of the possible confidential clinical data that might have influenced the results was not collected (oral contraceptive use, passive smoking effect, daily dose of nicotine).

\section{Conflict of Interest}

There is no conflict of interest.

\section{Acknowledgements}

Supported by Grant No. APVV-0672 from the Slovak APVV agency.

\section{References}

AJUEBOR MN, HOGABOAM CM, KUNKEL SL, PROUDFOOT AEI, WALLACE JL: The chemokine RANTES is a crucial mediator of the progression from acute to chronic colitis in the rat. J Immunol 166: 552-558, 2001.

ALLAIS L, SMET RD, VERSCHUERE S, TALAVERA K, CUVELIER CA, MAES T: Transient receptor potential channels in intestinal inflammation: What is the impact of cigarette smoking? Pathobiology 84: 1-15, 2017.

ALLAIS L, KERCKHOF FM, VERSCHUERE S, BRACKE KR, SMET RD, LAUKENS D, ABBEELE PV, VOS M, BOON N, BRUSSELLE GG, CUVELIER CA, WIELE T: Chronic cigarette smoke exposure induces microbial and inflammatory shifts and mucin changes in the murine gut. Environ Microbiol 18: 1352-1363, 2016.

ANDRES PG, BECK PL, MIZOGUCHI E, MIZOGUCHI A, BHAN AK, DAWSON T, KUZIEL WA, MAEDA N, MACDERMOTT RP, PODOLSKY DK, REINECKER HC: Mice with a selective deletion of the CC chemokine receptors 5 or 2 are protected from dextran sodium sulfate-mediated colitis: lack of CC chemokine receptor 5 expression results in a NK1.1+ lymphocyte-associated Th2-type immune response in the intestine. J Immunol 164: 6303-6312, 2000.

ARNSON Y, SHOENFELD Y, AMITAL H: Effects of tobacco smoke on immunity, inflammation and autoimmunity. J Autoimmun 34: J258-J265, 2010. 
BAUMGART DC, SANDBORN WJ: Crohn's disease. Lancet 380: 1590-1605, 2012.

BERKOWITZ L, SCHULTZ BM, SALAZAR GA, PARDO-ROA C, SEBASTIAN VP, ALVAREZ-LOBOS MM, BUENO SM: Impact of cigarette smoking on the gastrointestinal tract inflammation: opposing effects in crohn's disease and ulcerative colitis. Front Immunol 9: 74, 2018.

BIEDERMANN L, BRULISAUER K, ZEITZ J, FREI P, SCHARL M, VAVRICKA SR, FRIED M, LOESSNER MJ, ROGLER G, SCHUPPLER M: Smoking cessation alters intestinal microbiota: insights from quantitative investigations on human fecal samples using FISH. Inflamm Bowel Dis 20: 1496-1501, 2014.

CANTO E, RICART E, MONFORT D, GONZALEZ-JUAN D, BALANZO J, RODRIGUEZ-SANCHEZ JL, VIDAL S: TNF alpha production to TLR2 ligands in active IBD patients. Clin Immunol 119: 156-165, 2006.

DANESE S, GASBARRINI A: Chemokines in inflammatory bowel disease. J Clin Pathol 58: 1025-1027, 2005.

DE SOUZA, HS, FIOCCHI C: Immunopathogenesis of IBD: current state of the art. Nat Rev Gastroenterol Hepatol 13: 13-27, 2016.

FAN Y, LIU B: Expression of Toll-like receptors in the mucosa of patients with ulcerative colitis. Exp Ther Med 9: 1455-1459, 2015.

GOLOVICS PA, LAKATOS L, MANDEL MD, LOVASZ BD, VEGH Z, KURTI Z, SZITA I, KISS LS, PANDUR T, LAKATOS PL: Prevalence and predictors of hospitalization in Crohn's disease in a prospective populationbased inception cohort from 2000-2012. World J Gastroenterol 21: 7272-7280, 2015.

GOMES, JP, WATAD A, SHOENFELD Y: Nicotine and autoimmunity: The lotus' flower in tobacco. Pharmacol Res 128: 101-109, 2018.

GUNALTAY S, KUMAWAT AK, NYHLIN N, BOHR J, TYSK C, HULTGREN O, HULTGREN HORNQUIST E: Enhanced levels of chemokines and their receptors in the colon of microscopic colitis patients indicate mixed immune cell recruitment. Mediators Inflamm 2015: 132458, 2015.

HASNIS E, BAR-SHAI M, BURBEA Z, REZNICK AZ: Mechanisms underlying cigarette smoke-induced NF-kappaB activation in human lymphocytes: the role of reactive nitrogen species. J Physiol Pharmacol 5: 275-287, 2007.

CHINEN I, NAKAHAMA T, KIMURA A, NGUYEN NT, TAKEMORI H, KUMAGAI A, KAYAMA H, TAKEDA K, LEE S, HANIEH H, RIPLEY B, MILLRINE D, DUBEY PDK, NYATI KK, FUJII-KURIYAMA Y, CHOWDHURY K, KISHIMOTO T: The aryl hydrocarbon receptor/microRNA-212/132 axis in $\mathrm{T}$ cells regulates IL-10 production to maintain intestinal homeostasis. Int Immunol 27: 405-415, 2015.

LACKEYRAM D, YOUNG D, KIM CJ, YANG C, ARCHBOLD TL, MINE Y, FAN MZ: Interleukin-10 is differentially expressed in the small intestine and the colon experiencing chronic inflammation and ulcerative colitis induced by dextran sodium sulfate in young pigs. Physiol Res 66: 147-162, 2017.

LAKATOS PL, VEGH Z, B. LOVASZ BD, DAVID G, PANDUR T, ERDELYI Z, SZITA I, MESTER G, BALOGH M, SZIPOCS I, MOLNAR C, KOMAROMI E, GOLOVICS PA, MANDEL M, HORVATH A, SZATHMARI M, KISS LS, LAKATOS L: Is current smoking still an important environmental factor in inflammatory bowel diseases? Results from a population-based incident cohort. Inflamm Bowel Dis 19: 1010-1017, 2013.

LAKHAN SE, KIRCHGESSNER A: Anti-inflammatory effects of nicotine in obesity and ulcerative colitis. $J$ Transl Med 9: 129, 2011

LAWRANCE IC, MURRAY K, BATMAN B, GEARRY RB, GRAFTON R, KRISHNAPRASAD K, ANDREWS JM, PROSSER R, BAMPTON PA, COOKE SE, MAHY G, RADFORD-SMITH G, CROFT A, HANIGAN K: Crohn's disease and smoking: is it ever too late to quit? J Crohns Colitis 7: 665-671, 2013.

LEE G, JUNG KH, SHIN D, LEE C, KIM W, LEE S, KIM J, BAE H: Cigarette Smoking Triggers Colitis by IFN-gamma(+) CD4(+) T Cells. Front Immunol 8: 1344, 2017.

LEE J, RACHMILEWITZ D, RAZ E: Homeostatic effects of TLR9 signaling in experimental colitis. Ann N Y Acad Sci. 1072: 351-355, 2006.

MACKERN-OBERTI JP, OBREQUE J, MENDEZ GP, LLANOS C, KALERGIS AM: Carbon monoxide inhibits T cell activation in target organs during systemic lupus erythematosus. Clin Exp Immunol 182: 1-13, 2015.

MAHID SS, MINOR KS, SOTO RE, HORNUNG CA, GALANDIUK S: Smoking and inflammatory bowel disease: a meta-analysis. Mayo Clin Proc 81: 1462-1471, 2006. 
MAZZUCCHELLI L, HAUSER C, ZGRAGGEN K, WAGNER HE, HESS MW, LAISSUE JA, MUELLER C: Differential in situ expression of the genes encoding the chemokines MCP-1 and RANTES in human inflammatory bowel disease. $J$ Pathol 178: 201-206, 1996.

MONTELEONE I, RIZZO A, SARRA M, SICA G, SILERI P, BIANCONE L, MACDONALD TT, PALLONE F, MONTELEONE G: Aryl hydrocarbon receptor-induced signals up-regulate IL-22 production and inhibit inflammation in the gastrointestinal tract. Gastroenterology 141: 237-248, 2011.

NIESSNER M, VOLK BA: Altered Th1/Th2 cytokine profiles in the intestinal mucosa of patients with inflammatory bowel disease as assessed by quantitative reversed transcribed polymerase chain reaction (RT-PCR). Clin Exp Immunol 101: 428-435, 1995.

NIKFAR S, EHTESHAMI-ASHAR S, RAHIMI R, ABDOLLAHI M: Systematic review and meta-analysis of the efficacy and tolerability of nicotine preparations in active ulcerative colitis. Clin Ther 32: 2304-2315, 2010.

OBERG M, JAAKKOLA MS, WOODWARD A, PERUGA A, PRUSS-USTUN A: Worldwide burden of disease from exposure to second-hand smoke: a retrospective analysis of data from 192 countries. Lancet 377: 139-146, 2011.

PARKES GC, WHELAN K, LINDSAY JO: Smoking in inflammatory bowel disease: impact on disease course and insights into the aetiology of its effect. J Crohns Colitis 8: 717-725, 2014.

PULLAN SD, RHODES J, GANESH S, MANI V, MORRIS JS, WILLIAMS GT, NEWCOMBE RG, RUSSELL MA, FEYERABEND C, THOMAS GA: Transdermal nicotine for active ulcerative colitis. $N$ Engl J Med 330: 811-15, 1994.

RIQUELME SA, CARRENO LJ, ESPINOZA JA, MACKERN-OBERTI JP, ALVAREZ-LOBOS MM, RIEDEL CA, BUENO SM, KALERGIS AM: Modulation of antigen processing by haem-oxygenase 1. Implications on inflammation and tolerance. Immunology 149: 1-12, 2016.

SAEED RW, VARMA S, PENG-NEMEROFF T, SHERRY B, BALAKHANEH D, HUSTON J, TRACEY KJ, AL-ABED Y, METZ CN: Cholinergic stimulation blocks endothelial cell activation and leukocyte recruitment during inflammation. $J$ Exp Med 201: 1113-1123, 2005.

SEKSIK P, NION-LARMURIER I, SOKOL H, BEAUGERIE L, COSNES J: Effects of light smoking consumption on the clinical course of Crohn's disease. Inflamm Bowel Dis 15: 734-741, 2009.

SHEIKH SZ, HEGAZI RA, KOBAYASHI T, ONYIAH JC, RUSSO SM, MATSUOKA K, SEPULVEDA AR, LI F, OTTERBEIN LE, PLEVY SE: An anti-inflammatory role for carbon monoxide and heme oxygenase-1 in chronic Th2-mediated murine colitis. J Immunol 186: 5506-5513, 2011.

TALHOUT R, SCHULZ T, FLOREK E, VAN BENTHEM J, WESTER P, OPPERHUIZEN A: Hazardous compounds in tobacco smoke. Int J Environ Res Public Health 8: 613-628, 2011.

UENO A, JIJON H, TRAVES S, CHAN R, FORD K, BECK PL, IACUCCI M, FORT GASIA M, BARKEMA HW, PANACCIONE R, KAPLAN GG, PROUD D, GHOSH S: Opposing effects of smoking in ulcerative colitis and Crohn's disease may be explained by differential effects on dendritic cells. Inflamm Bowel Dis 20: 800-810, 2014.

VERSCHUERE S, BRACKE KR, DEMOOR T, PLANTINGA M, VERBRUGGHE P, FERDINANDE L, LAMBRECHT BN, BRUSSELLE GG, CUVELIER CA: Cigarette smoking alters epithelial apoptosis and immune composition in murine GALT. Lab Invest 91: 1056-1067, 2011.

YAMAMOTO T, KEIGHLEY MR: Smoking and disease recurrence after operation for Crohn's disease. Br J Surg. 87: 398-404, 2000.

ZORZI F, MONTELEONE I, SARRA M, CALABRESE E, MARAFINI I, CRETELLA M, SEDDA S, BIANCONE L, PALLONE F, MONTELEONE G: Distinct profiles of effector cytokines mark the different phases of Crohn's disease. PLoS One 8: e54562, 2013.

ZUO L, LI Y, WANG H, WU R, ZHU W, ZHANG W, CAO L, GU L, GONG J, LI N, LI J: Cigarette smoking is associated with intestinal barrier dysfunction in the small intestine but not in the large intestine of mice. J Crohns Colitis 8: 1710-1722, 2014. 